\title{
Whose Freedom of Movement Is Worth Defending?
}

\author{
Sarah Fine
}

\begin{abstract}
'Should the UK remain a member of the European Union or leave the European Union?', the British government asked the electorate in a referendum on 23 June 2016. On 24 June, we awoke to the momentous news that a majority of voters had opted for 'LEAVE' (Brexit). Against this backdrop, the informative EUDO Citizenship debate on the relationship between EU citizenship and freedom of movement could hardly be more timely, and obviously has even greater poignancy following the historic Brexit decision.
\end{abstract}

Since the referendum question did not directly ask voters about migration, the Leave result itself cannot be interpreted straightforwardly as a rejection of EU freedom of movement. However, long before the votes were counted, commentators were connecting Brexit's popularity with widespread negative attitudes towards the free movement of EU citizens and net immigration figures (among many other factors, of course). ${ }^{1}$ The dominant view was that Leave voters tended to be particularly swayed by concerns about immigration control, as distinct from Remain voters who tended to prioritise economic arguments. ${ }^{2}$ As the Economist wrote several months ago, 'immigration is one subject on which Leave campaigners have a clear lead. The correlation between hostility to immigration and support for Brexit is high, so if they can turn the vote into one about migration, they will win'. ${ }^{3}$ Though analysts are still collecting and examining important data about vot-

1 'EU referendum: Concern over immigration delivers a "significant" poll boost to the Leave campaign as voters react to claims over UK border control', The Telegraph, 31 May 2016, available at http://www.telegraph.co.uk/ news/2016/05/30/ concern-over-immigration-delivers-a-significant-poll-boost-to-th/.

2 Hobolt, S. \& Wratil, C. (2016), 'Which argument will win the referendum immigration, or the economy?' LSE BrexitVote blog, available at http://blogs. lse.ac.uk/brexit/2016/06/21/ which-argument-will-win-the-referendum-immigration-or-the-economy.

3 'Let them not come', The Economist, 2 April 2016, available at https://www. economist.com/news/ britain/21695958-hostility-large-scale-european-union-migration-coulddecide-referendum-let-them-not-come. 
ing patterns, and digesting the results, there is no doubt that migration was a pivotal issue in the national debate. ${ }^{4}$ The Brexit side clearly considered free movement to be a central concern for the electorate. With their appealing tagline of 'take back control', the Leave campaign put migration at the heart of the argument in favour of withdrawing from the EU. On their official website, for example, they explained 'what would happen if we vote to leave the EU'. The second and third points (after the claim that 'we will be able to save $£ 350$ million a week'), were that 'we will be in charge of our own borders' and that 'we can be in charge of immigration'. They described immigration from the EU as 'out of control' and as a 'big strain on public services'. They also linked it with security concerns, stating that the 'EU Court' prevents Britain both from stopping 'violent convicted criminals coming here from Europe' and from 'deporting dangerous terror suspects'. ${ }^{5}$ In short, the Leave side presented freedom of movement as one of the core features-if not the core feature - of EU membership, and they clearly considered that highlighting this connection would be a vote-winner for the Brexit camp. On the other side, the Remain campaign's website and materials made little or no mention of free movement as a feature of EU membership, a silence which itself speaks volumes about general perceptions of this topic's selling power. $^{6}$

One of the most noteworthy issues discussed in the EUDO citizenship debate is the growing evidence that there is, as Rainer Bauböck explains in his contribution, a 'new political cleavage in Europe', which is 'most strongly articulated through citizens' attitudes towards European integration'. I think the emphasis on the differences between 'mobile' citizens, for whom freedom of movement represents exciting opportunities, and 'immobile' citizens, who associate free movement with serious costs to themselves and their communities, is especially illuminating for trying to interpret the various anti-EU developments across the continent, including the factors which have contributed to the Brexit result.

However, I want to focus on a crucial, related issue that was striking for its absence from Floris de Witte's kick-off contribution and the subsequent debate about the relationship between freedom of movement and EU citizenship - an issue which demands attention in any attempt to conceptualise the place of free movement in the European project. This issue is brought

\footnotetext{
4 See e.g. this interesting GQR poll conducted for the TUC, June 24-27, 2016, available at https://gqrr.app.box.com/s/xb5sfzo19btsn74vawnmu7mn033p1ary.

5 http://www.voteleavetakecontrol.org/why vote leave.html

6 http://www.strongerin.co.uk/\#MtGy8b0VE9ZhD3UD.97
} 
into stark relief by the on-going refugee crisis, the thousands of avoidable deaths so far this year in the Mediterranean, and the growing number of people stuck in makeshift camps in European countries. ${ }^{7}$ It is the fact that, beyond the political, cultural and socio-economic cleavages between citizens within Europe, there is a far greater and growing divide between European citizens and the people they want to keep out. European policymakers identify the refugee crisis and the 'heightened terrorist threat' as central challenges to the European free movement zone. It is not news that the free movement of European citizens is widely understood to rely on hard external European borders, and now also enhanced monitoring of movement between European states. But surely this has to factor into any response to Floris de Witte's question of whether there is 'any reason to defend free movement as the core of EU citizenship'.

Most importantly, the conspicuous refusal of the EU to respond humanely to refugees and other migrants seeking entry, as well as its collective failure to show solidarity with its own member states at the forefront of the crisis, cannot be neglected from this discussion. How can we try to defend free movement as the core of EU citizenship without considering what is happening right now at (and indeed within) the EU's own borders? ${ }^{8}$

Returning to the Brexit case, the refugee crisis and the EU's response to it featured prominently in the public debate about the costs and benefits of EU membership. The Brexiteers were accused of trying to stoke up antirefugee and anti-migrant fears, particularly with Nigel Farage's now infamous 'Breaking Point' poster, which pictured people crossing the Croatia-Slovenia border. ${ }^{9}$ But it is crucial to note that the Remain side raised the issue of refugees, too-we must not forget, for example, David Cameron's warnings that leaving the EU could mean that Calais-style camps move from France to the UK. ${ }^{10}$ In effect, both sides were arguing, either

7 'Migrant crisis: Greek islands see rising numbers in camps', $B B C$ News, 17 August 2016, available at http://www.bbc.com/news/world-europe-37099332.

8 'Greek refugee camp is "as bad as a Nazi concentration camp", says minister', Independent, 18 March 2016, available at http://www.independent.co.uk/news/ world/europe/idomeni-refugee-dachau-nazi-concentration-camp-greek-minister-a6938826.html.

9 'Nigel Farage's anti-migrant poster reported to police', The Guardian, 16 June 2016, available at https://www.theguardian.com/politics/2016/jun/16/ nigel-farage-defends-ukip-breaking-point-poster-queue-of-migrants.

10 'David Cameron says Calais refugee camps could move to Kent after EU exit', Independent, 8 February 2016, available at http://www.independent.co.uk/ news/uk/politics/migrant-refugee-camp-calais-britain-brexit-eu-exit-david- 
explicitly or implicitly, that their position offered the best prospects for keeping refugees and other unwanted migrants out of the UK. As long as the EU itself continues to present refugees as a problem to be kept at bay, with repeated promises to strengthen its borders against unwanted arrivals, those of us who wish to defend freedom of movement as a core component of EU citizenship have to ask ourselves not just about Europe's 'immobile' citizens who associate free movement with unpalatable costs, but about the people on the wrong side of Europe's territorial and civic borders who are paying the ultimate price.

cameron-kent-a6860466.html.

Open Access This chapter is licensed under the terms of the Creative Commons Attribution 4.0 International License (http://creativecommons.org/licenses/by/4.0/), which permits use, sharing, adaptation, distribution and reproduction in any medium or format, as long as you give appropriate credit to the original author(s) and the source, provide a link to the Creative Commons license and indicate if changes were made.

The images or other third party material in this chapter are included in the chapter's Creative Commons license, unless indicated otherwise in a credit line to the material. If material is not included in the chapter's Creative Commons license and your intended use is not permitted by statutory regulation or exceeds the permitted use, you will need to obtain permission directly from the copyright holder. 